\title{
Effect of PEG Induced Water Stress on Germination and Seed Vigour of Bitter Gourd Genotypes
}

\author{
S. $\operatorname{Das}^{1 *}$, S. Sahu ${ }^{2}$, K. C. Muduli ${ }^{1}$, S. Mohanty ${ }^{3}$, M. Priyadarshini ${ }^{1}$, \\ R. Bhol ${ }^{4}$ and J. K. Beura ${ }^{3}$
}

${ }^{1}$ Department of Seed Science \& Technology, ${ }^{4}$ Department of Plant Physiology, Odisha University of Agriculture and Technology, Bhubaneswar, Odisha, India

${ }^{2}$ All India Coordinated Research Project on Vegetable Crops, Odisha University of Agriculture and Technology, Bhubaneswar, Odisha, India

${ }^{3}$ All India Coordinated Research Project on Seed Technology Research (NSP) Crops, Odisha University of Agriculture and Technology, Bhubaneswar, Odisha, India

*Corresponding author

\begin{abstract}
A B S T R A C T
In the present investigation an attempt has been made to assess germination and seed vigour of six bitter gourd genotypes under PEG induced water stress condition. The experiment was laid out in a completely randomized design with three replications. Water stress at laboratory was induced through PEG 6000. The optimum stress levels were maintained at $0,-0.05,-0.1,-0.2,-0.4 \&-0.6 \mathrm{MPa}$. Observations were recorded on germination count, root length, shoot length, seedling length, and seed vigour indices. Significant variation was observed among the bitter gourd genotypes in respect of germination count under normal as well as stress conditions. Under normal condition germination count varied from 65.3 to $90.0 \%$; seed vigour index-I of the genotypes ranged from 1294.90 (V1) to 2275.20 (V6) with a mean of 1768.18; seed vigour index-II was maximum in V6 (9.99) and minimum in V1 (6.60). Under water stress condition, the mean germination count at $-0.05,-0.1,-0.2,-0.4 \&-0.6 \mathrm{MPa}$ was $72.85 \%, 61.38 \%, 54.58 \%$, $46.08 \%$ and $38.25 \%$ respectively. The mean SV-I value at $-0.05,-0.1,-0.2,-0.4 \&-0.6$ MPa was $1307.33,868.94,721.76,547.62 \& 401.03$ respectively. These findings indicated that germination and seed vigour of bitter gourd genotypes decrease with the increase in water deficit.
\end{abstract}

\section{Introduction}

Bitter gourd (Momordica charantia Linn.) belongs to the family of Cucurbitaceae and known as one of the bitterest fruit. It is a tropical and subtropical climber. Bitter gourd is known for centuries for its pharmacological activities, and nutritional properties. It is one of the most important and popular cucurbit vegetable grown in India. In Odisha, it is also 
a highly demanded vegetable throughout the year. Bitter gourd is an exceptional vegetable giving nutrition as well as offering a few components which show medicinal properties against a wide number of diseases.

Recently the cultivation of bitter gourd has gained popularity because of its anti-diabetic property and nutritive value among the consumers. But low yield potential is a major problem in the country as well as in the state. One of the major causes of low yield is scarcity of good quality seeds. Use of quality seeds encourages rapid and uniform emergence of vigorous seedlings of the desired cultivar which is the key events to ensure high yield. The physiological potential of seeds of different cultivars must be examined in the laboratory before their entry to the farmer's field.

Plants exposed to water deficit show reduced germination and seedling growth (Kaur et al., 1998). Water deficit is recognized as a potent abiotic stress which causes substantial reductions in plant growth and development that resulting in significant yield loss among different crops than other stresses across the globe (Khan et al., 2018). Water deficit affects the germination of seed and the growth of seedlings negatively (Van-Den-Berg and Zeng, 2006). Several research works have been conducted to study effect of water stress on different cereals, pulses and oil seeds. Literature regarding the effect of water stress on germination and seed vigour in bitter gourd is not available. Thus in the present investigation we studied effect of PEG induced water stress on germination and seed vigour of bitter gourd genotypes.

\section{Materials and Methods}

The materials of the present study comprised of six bitter gourd genotypes namely Chandramukhi, Kantali, Katahi, Raksha,
Tanindo Long and Uncha Bolder and they were commercially cultivated in different regions of Odisha. The experiment was laid out in a completely randomised design with three replications in the department of Seed Science \& Technology, Odisha University of Agriculture \&Technology, Bhubaneswar, India.

Fifty healthy and well filled seeds were taken from each genotype per replication and per each treatment. Then the seeds were sown in paper towel rolls imbibed with polyethylene glycol solutions (PEG 6000) using the levels of osmotic potential: 0 (control); -0.05, -0.1, $0.2,-0.4$ and $-0.6 \mathrm{MPa}$. Then the paper towels were placed in meg bins containing PEG solutions of different osmotic potentials at room temperature. Seeds were put for germination following between paper method, using three sheets of paper towel moistened with the PEG 6000 solutions with addition of fungicide bavistin $0.2 \%$ concentration. Fresh PEG 6000 solution at different osmotic potential was added to the bin whenever required. Germination was recorded on $14^{\text {th }}$ day after treatment. Ten seedlings were selected randomly on $14^{\text {th }}$ day to record observation on different physiological traits like root length, shoot length, seedling length, root length to shoot length ratio, dry weight of seedling, seed vigour index-I \& II. The data were statistically analysed following SAS 9.0 version. The level of significance used in $\mathrm{F}$ test was $\mathrm{P}=0.01$.

\section{Results and Discussion}

\section{Germination count}

Final germination count of the genotypes is presented in Table 1. Significant variation was observed among the genotypes in respect of germination count. The genotype Uncha Bolder (V6) recorded the highest germination count $(90.0 \%)$ followed by Tanindo long 
(V5; $83.3 \%$ ) under normal condition. Out of the six genotypes, Chandramukhi (V1) had the lowest germination count $(65.3 \%)$ under normal condition.

At $-0.1 \mathrm{MPa}$ water potential, germination count of the genotypes ranged from $50.5 \%$ to $68.9 \%$. V2 recorded the highest germination count $(68.9 \%)$ and it was at par with V3 $(63.2 \%), \mathrm{V} 4(65.7 \%)$ and V6 (63.6 \%) and significantly different from V1 $(50.5 \%)$ and V5 (56.4\%). At $-0.2 \mathrm{MPa}$, germination count varied from 45.0 to $65.0 \%$. V2 ranked first $(65.0 \%)$ and V6 (45.0\%) scored the lowest germination. V2, V3 and V4 were at par with each other. At $-0.4 \mathrm{MPa}$, it was observed that V1 (34.4\%), V5 (39.7\%) and V6 (33.3\%) were at par with each other having below 40.0 $\%$ germination whereas $\mathrm{V} 2, \mathrm{~V} 3$, and $\mathrm{V} 4$ had in between 60.0 to $70.0 \%$ germination count and these three were at par with each other. At lower water potential $(-0.6 \mathrm{MPa})$ the highest germination was exhibited by V4 $(48.1 \%)$ and it was at par with V2 (45.2\%) \& V3 (45.4 \%). V5 recorded the lowest germination count $(28.0 \%)$.

The mean germination count at $0.0,-0.05$, $0.1,-0.2,-0.4 \&-0.6 \mathrm{MPa}$ was $77.85 \%, 72.85$ $\%, 61.38 \%, 54.58 \%, 46.08 \%$ and $38.25 \%$ respectively. From the above results it was observed that germination count of bitter gourd genotypes decreased with the increase in water scarcity or increase in PEG concentration. Reduction in germination \% was the lowest at $-0.05 \mathrm{MPa}$ (6.55) and the highest at $-0.6 \mathrm{MPa}$ (50.14). Fifty percent reduction was observed at $-0.6 \mathrm{MPa}$ and this may be treated as optimum stress to distinguish vigorous bitter gourd genotypes.

\section{Root length}

Root growth is an important parameter to judge seed performance of different genotypes under water stress condition. In the present study root length of the genotypes is presented in Fig.1. Significant differences were observed among the genotypes at different water potentials. Root length of the genotypes under normal condition varied from 9.64 to $13.65 \mathrm{~cm}$. The longest root $(13.65 \mathrm{~cm})$ was observed in the genotype Uncha Bolder (V6) and the shortest root (9.64 $\mathrm{cm}$ ) was found in Chandramukhi (V1).

At $-0.05 \mathrm{MPa}$ water potential, the genotypes differ significantly in their root length that ranged from 6.89 to $11.86 \mathrm{~cm}$ with a mean of $9.21 \mathrm{~cm}$. Uncha Bolder (V6) produced the longest root $(11.86 \mathrm{~cm})$ and this value was significantly higher than others. At $-0.1 \mathrm{MPa}$, root length of the genotypes ranged from 6.07 to $7.28 \mathrm{~cm}$. V5 recorded the highest root length $(7.28 \mathrm{~cm})$ and it was at par with $\mathrm{V} 2$ $(6.66 \mathrm{~cm}), \mathrm{V} 3(6.97 \mathrm{~cm}, \mathrm{~V} 4(7.15 \mathrm{~cm})$ and V6 $(6.74 \mathrm{~cm})$ and significantly different from V1 $(6.07 \mathrm{~cm})$. At $-0.2 \mathrm{MPa}$, root length varied from 5.46 to $6.54 \mathrm{~cm}$ with a mean of $5.80 \mathrm{~cm}$. Raksha (V4) ranked first $(6.54 \mathrm{~cm})$ and it was only at par with Katahi (V3; $6.37 \mathrm{~cm}$ ). Tanindo long (V5) exhibited the shortest root length $(4.86 \mathrm{~cm})$. At $-0.4 \mathrm{MPa}$ water potential, it was observed that Tanindo long (V5) had the shortest root $(4.66 \mathrm{~cm})$ and it was at par with Chandramukhi (V1; $4.79 \mathrm{~cm})$, Kantali (V2; $5.26 \mathrm{~cm}$ ), and Uncha Bolder (V6; 4.71 $\mathrm{cm})$. Raksha (V4) recorded the longest root of $6.13 \mathrm{~cm}$. At lower water potential (-0.6 MPa) the highest root length was exhibited by $\mathrm{V} 2$ $(5.01 \mathrm{~cm})$ and it was at par with $\mathrm{V} 3(4.92 \mathrm{~cm})$ \& V4 $(4.79 \mathrm{~cm})$. V1 recorded the shortest root $(4.19 \mathrm{~cm})$.

The mean root length at $0.0,-0.05,-0.1,-0.2$, $-0.4 \&-0.6 \mathrm{MPa}$ was found to be $11.66,9.21$, $6.81,5.80,5.22 \& 4.62 \mathrm{~cm}$ respectively. From these results it was observed that the genotypes behaved differently at different water potentials in respect of root length. Root length was found to decrease with the increase in PEG 6000 concentrations that 
indicated water scarcity at the time of germination has detrimental effect on root development.

\section{Shoot length}

Shoot length of the bitter gourd genotypes at different osmotic potential of PEG 6000 is presented in Table 2. Shoot length of the genotypes was influenced by different concentrations of PEG 6000. Under normal condition the genotype Tanindo long recorded the maximum shoot length of $12.56 \mathrm{~cm}$ and the shortest shoot $(9.27 \mathrm{~cm})$ was observed in case of Kantali (V2).

At $-0.05 \mathrm{MPa}$ water potential, shoot length varied from 7.57 to $9.32 \mathrm{~cm}$ with a mean of $8.56 \mathrm{~cm}$. Chandramukhi had the shortest shoot length. Raksha had the longest shoot $(9.32 \mathrm{~cm})$ and it was at par with Uncha Bolder $(9.30 \mathrm{~cm}) \&$ Katahi $(8.96 \mathrm{~cm})$. At $-0.1 \mathrm{MPa}$ water potential, shoot length of the genotypes was found to decrease as compared to shoot length at $-0.05 \mathrm{MPa}$ water potential. Shoot length of the genotypes ranged from 5.45 to $9.94 \mathrm{~cm}$ and significant difference was observed among the genotypes. Uncha Bolder produced the longest shoot of $9.94 \mathrm{~cm}$ followed by Kantali $(8.34 \mathrm{~cm})$. Chandramukhi recorded the shortest shoot $(5.45 \mathrm{~cm})$. Kantali, Katahi and Raksha were at par with each other. At $-0.2 \mathrm{MPa}$ shoot length of the genotypes ranged from 4.71 to $7.85 \mathrm{~cm}$ and significant difference was observed among the genotypes. Katahi produced the longest shoot of $7.85 \mathrm{~cm}$ followed by Kantali (7.73 $\mathrm{cm})$. At $-0.4 \mathrm{MPa}$ water potential, shoot length of the genotypes ranged from 4.36 to $7.78 \mathrm{~cm}$ and significant difference was observed among the genotypes. Katahi produced the longest shoot of $7.78 \mathrm{~cm}$ followed by Kantali $(7.73 \mathrm{~cm})$. At $-0.6 \mathrm{MPa}$ water potential, shoot length of the genotypes ranged from 3.33 to $6.97 \mathrm{~cm}$ and significant difference was observed among the genotypes. Katahi produced the longest shoot of $6.97 \mathrm{~cm}$ followed by Kantali $(6.76 \mathrm{~cm})$.

The mean shoot length (genotypic) at 0.0, $0.05,-0.1,-0.2,-0.4 \&-0.6 \mathrm{MPa}$ was found to be $10.93,8.56,7.84,6.73,6.34 \& 5.60 \mathrm{~cm}$ respectively. From these results it was revealed that shoot length decreases with the increase in PEG 6000 concentration (or decrease in water potential) that indicated water deficit at the time of germination has adverse effect on shoot growth.

\section{Root length to shoot length ratio}

Root length to shoot length ratio of bitter gourd genotypes at different water potential was presented in Table 3. Significant difference was observed among the genotypes at different osmotic potentials. Reduction in root shoot ratio under stress is an indicator of stunted root growth, whereas an increase in root shoot ratio implies more root elongation relative to shoots to reach deeper soil foils to absorb water. Under normal condition root to shoot length ratio was $0.95,1.26,1.03,1.02$, $0.97 \& 1.17$ in $\mathrm{V} 1, \mathrm{~V} 2, \mathrm{~V} 3, \mathrm{~V} 4, \mathrm{~V} 5$ \& V6 respectively. In case of $\mathrm{V} 3 \& \mathrm{~V} 4$ the ratio approached nearly to unit (1.0) where as the ratio was significantly more than unity in case of V2 and V6.

At -0.05 MPa osmotic potential, root length to shoot length ratio was the highest in case of Uncha Bolder (1.28) followed by Tanindo Long (1.20). The lowest ratio was recorded in case of Chandramukhi. At a uniform shoot length of all the genotypes, root extension was deeper in case of Uncha Bolder, Tanindo Long and Katahi. At $-0.1 \mathrm{MPa}$ osmotic potential, root length to shoot length ratio was the highest in case of Chandramukhi (1.11) followed by Uncha Bolder (1.05) and Tanindo Long (1.00). High ratio indicated longer root length and low ratio indicated shorter root length as compared to unit shoot length. At - 
$0.2 \mathrm{MPa}$ osmotic potential, root length to shoot length ratio was the highest in case of Chandramukhi (1.16) followed by Raksha (0.95). Uncha Bolder recorded the lowest ratio. At $-0.4 \mathrm{MPa}$ osmotic potential, genotypes Chandramukhi, Raksha and Tanindo long had higher root length to shoot length ratio $(1.10,0.89$, and 0.91). Root length to shoot length ratio varied from 0.71 to 1.10 . At $-0.6 \mathrm{MPa}$ osmotic potential, genotypes showed significant difference in their root length to shoot length ratio. Chandramukhi recorded the highest ratio (1.26) followed by Tanindo long (1.18). Kantali, Katahi, and Raksha were at par with each other.

\section{Seedling length}

Vigorous seeds more efficiently mobilize reserves from storage tissues to the embryo axis and this capacity is reflected in seedling growth. Therefore, the evaluation of seedling length constitutes important vigour parameter. In the present study seedling length of bitter gourd genotypes at different osmotic potential of PEG 6000 is presented in Table 4. Genotypic performance in respect of seedling length was significantly influenced by osmotic potential of PEG 6000. Significant difference was among the genotypes for their seedling length. The maximum seedling length under control condition was observed in V6 $(25.28 \mathrm{~cm})$ and it was at par with V5 $(24.70 \mathrm{~cm}) . \mathrm{V} 1$ recorded the lowest seedling length of $19.83 \mathrm{~cm}$.

At $-0.05 \mathrm{MPa}$ osmotic potential, Uncha Bolder recorded the highest seedling length $(21.16 \mathrm{~cm})$ and it was significantly higher than others. Chandramukhi had the lowest seedling length of $14.46 \mathrm{~cm}$. Katahi (18.90 $\mathrm{cm})$, Raksha $(18.12 \mathrm{~cm})$ and Tanindo long $(17.16 \mathrm{~cm})$ were at par with each other. At $0.1 \mathrm{MPa}$ osmotic potential, seedling length of the genotypes varied from 11.52 to $15.14 \mathrm{~cm}$ with a mean of $14.06 \mathrm{~cm}$. The highest seedling length was observed in Raksha $(15.14 \mathrm{~cm})$ and it was at par with Kantali $(15.00 \mathrm{~cm})$, Katahi $(15.00 \mathrm{~cm})$ and Tanindo long $(14.55 \mathrm{~cm})$. The lowest seedling length was observed in Chandramukhi $(11.52 \mathrm{~cm})$. At $-0.2 \mathrm{MPa}$ osmotic potential, seedling length of the genotypes varied 10.17 to 15.64 $\mathrm{cm}$ with a mean of $13.15 \mathrm{~cm}$. Uncha Bolder had the highest seedling length of $15.64 \mathrm{~cm}$ and it was at par with Katahi $(14.22 \mathrm{~cm})$. At $0.4 \mathrm{MPa}$ osmotic potential, significant differences was observed among the genotypes. Seedling length varied from 9.15 to $13.56 \mathrm{~cm}$. Seedling length was the lowest in Chandramukhi $(9.15 \mathrm{~cm})$ and the highest in Katahi $(13.56 \mathrm{~cm})$. At $-0.6 \mathrm{MPa}$ osmotic potential, Chandramukhi, Kantali, Katahi, Raksha, Tanindo long and Uncha Bolder had seedling length of $7.51,11.77,11.89,11.16$, $8.34 \& 10.57 \mathrm{~cm}$. Chandramukhi and Tanindo Long were at par with each other. Kantali, Katahi and Raksha had longer seedling length and they were at par with each other.

The mean seedling length over the genotypes at $0.0,-0.05,-0.1,-0.2,-0.4$ and $-0.6 \mathrm{MPa}$ water potential was $22.54,17.77,14.06$, $13.15,11.56 \& 10.21 \mathrm{~cm}$ respectively. Results of this study indicated that seedling length of genotypes decreased with the increase in PEG concentrations.

\section{Seedling dry weight}

Seedling dry weight is one of the physiological attribute to assess seedling vigour. Seedling dry weight of the genotypes is given in Table 5. Significant differences were observed among the genotypes at different water potentials. Under normal condition seedling dry weight ranged from 0.101 to $0.113 \mathrm{~g}$ with an average of $0.18 \mathrm{~g}$.

At $-0.05 \mathrm{MPa}$ water potential, the maximum dry weight was scored by Tanindo Long 
$(0.112 \mathrm{~g})$ and the minimum by Chandramukhi $(0.084 \mathrm{~g})$. The genotypes found to possess above mean dry weight $(0.098 \mathrm{~g})$ were Kantali (0.104 g), Katahi $(0.102$ g) and Tanindo Long $(0.112 \mathrm{~g})$ and they were at par with each other. At $-0.1 \mathrm{MPa}$ water potential, the maximum dry weight was observed in Tanindo Long (0.108 g) and the minimum in Kantali $(0.073 \mathrm{~g})$. The genotypes found to possess above mean dry weight $(0.071 \mathrm{~g})$ were Chandramukhi (0.079 g), Katahi (0.090 g), Raksha (0.078 g) and Uncha Bolder (0.085 g). At $-0.2 \mathrm{MPa}$ water potential, the maximum dry weight was recorded by Katahi $(0.075 \mathrm{~g})$ and the minimum by Chandramukhi $(0.053$ g).

The genotypes found to possess above mean dry weight $(0.067 \mathrm{~g})$ were Raksha $(0.071 \mathrm{~g})$ and Uncha Bolder (0.068 g). At $-0.4 \mathrm{MPa}$ water potential, the maximum dry weight was recorded by Katahi $(0.057 \mathrm{~g})$ and the minimum by Tanindo Long $(0.037 \mathrm{~g})$. The genotypes found to possess above mean dry weight $(0.049 \mathrm{~g})$ were Raksha $(0.055 \mathrm{~g})$ and Uncha Bolder $(0.056 \mathrm{~g})$. At $-0.6 \mathrm{MPa}$ water potential, the maximum dry weight was recorded by Katahi $(0.042 \mathrm{~g})$ and the minimum by Tanindo Long $(0.030 \mathrm{~g})$. The genotypes found to possess above mean dry weight $(0.035 \mathrm{~g})$ were Chandramukhi $(0.036$ $\mathrm{g}$ ), and Uncha Bolder (0.37 g).

The mean genotypic dry weight at $0.0,-0.05$, $-0.1,-0.2,-0.4 \&-0.6 \mathrm{MPa}$ was $0.108,0.098$, $0.071,0.067,0.049 \& 0.035 \mathrm{~g}$ respectively. This result indicated that dry weight decreased with the increase in water stress.

\section{Seed vigour index-I}

Seed vigour index-I of bitter gourd genotypes at different water potential is mentioned in Fig.2. From the data it was observed that the genotypes were different in their seed vigour at different water potentials. Seed vigour index-I of the genotypes under normal condition ranged from 1294.90 (V1) to 2275.20 (V6) with a mean of 1768.18.

At $-0.05 \mathrm{MPa}$ water potential, the maximum seed vigour index was recorded in Uncha Bolder (1781.67) and the minimum vigour was recorded in Chandramukhi (848.80). Katahi (1323.00), Raksha (1333.63) and Tanindo Long (1377.95) had above average (1307.33) vigour and they were at par with each other. At $-0.1 \mathrm{MPa}$ water potential, the maximum seed vigour index was recorded in Kantali (1033.50) and the minimum vigour was recorded in Chandramukhi (581.76). Katahi (948.00), Raksha (994.70) had above average (868.94) vigour and they were at par with each other. At -0.2 MPa water potential, the maximum seed vigour index was recorded in Kantali (885.30) and the minimum vigour was recorded in Chandramukhi (463.75). Katahi (857.47), Raksha (848.14) had above average (721.76) vigour and they were at par with each other. At $-0.4 \mathrm{MPa}$ water potential, the maximum seed vigour index was recorded in Katahi (813.60) and the minimum vigour was recorded in Chandramukhi (581.76). Katahi (948.00), Raksha (314.76) had above average (547.62) vigour and they were at par with each other. At $-0.6 \mathrm{MPa}$ water potential, the maximum seed vigour index was recorded in Katahi (539.81) and the minimum vigour was recorded in Chandramukhi (244.83). Kantali (532.00), Raksha (536.80) had above average (401.03) vigour and they were at par with each other.

The mean SV-I at $0.0,-0.05,-0.1,-0.2,-0.4 \&$ $-0.6 \mathrm{MPa}$ was $1768.18,1307.33,868.94$, 721.76, $547.62 \& 401.03$ respectively. This result indicated that seed vigour decreased with the decrease in water potential.

\section{Seed vigour index-II}

Seed vigour index-II of bitter gourd genotypes at different water potential is mentioned in Fig.3. From the data it was 
observed that the genotypes were significantly different in their seed vigour index-II at different water potentials. Under normal condition, seed vigour index-II was maximum in V6 (9.99) and minimum in V1 (6.60).

At $-0.05 \mathrm{MPa}$ water potential, the maximum seed vigour index-II was recorded in Tanindo Long (8.99) and the minimum vigour was recorded in Chandramukhi (4.93). Kantali (7.31), Katahi (7.14), Raksha (7.21) and Uncha Bolder (7.24) had above average (7.14) vigour and they were at par with each other. At $-0.1 \mathrm{MPa}$ water potential, the maximum seed vigour index-II was recorded in Tanindo Long (6.09) and the minimum vigour was recorded in Chandramukhi (3.99). Katahi (5.69), Raksha (7.21) and Uncha Bolder (5.41) had above average (5.22) vigour and they were at par with each other. At $-0.2 \mathrm{MPa}$ water potential, the maximum seed vigour index-II was recorded in Katahi (4.52) and the minimum vigour was recorded in Chandramukhi (2.42). Kantali (4.29) and Raksha (4.49) had above average (3.66) vigour and they were at par with each other. At -0.4 MPa water potential, the maximum seed vigour index-II was recorded in Katahi (3.42) and the minimum vigour was recorded in Tanindo Long (1.47). Kantali (2.60) and Raksha (2.96) had above average (2.31) vigour and they were at par with each other. At -0.6 MPa water potential, the maximum seed vigour index-II was recorded in Katahi (1.91) and the minimum vigour was recorded in Tanindo Long (0.84). Kantali (1.49) and Raksha (1.49) had above average (2.31) vigour and they were at par with Katahi (1.91).

The mean SV-II value at $0.0,-0.05,-0.1,-0.2$, $-0.4 \&-0.6 \mathrm{MPa}$ was $8.46,7.14,5.22,3.66$, $2.31 \& 1.34$ respectively. This result indicated that seed vigour index-II decreased with the increase in water stress.

Table.1 Final germination count $(\%)$ of bitter gourd genotypes at different osmotic potential of PEG 6000

\begin{tabular}{|l|c|c|c|c|c|c|}
\hline \multirow{2}{*}{ Genotype } & \multicolumn{5}{|c|}{ Germination count } \\
\cline { 2 - 7 } & $\mathbf{0 . 0 ~ M P a}$ & $\mathbf{- 0 . 0 5}$ & $\mathbf{- 0 . 1}$ & $\mathbf{- 0 . 2}$ & $\mathbf{- 0 . 4}$ & $\mathbf{- 0 . 6}$ \\
& $(\mathbf{n o r m a l})$ & $\mathbf{M P a}$ & $\mathbf{M P a}$ & $\mathbf{M P a}$ & $\mathbf{M P a}$ & $\mathbf{M P a}$ \\
\hline V1. Chandramukhi & 65.3 & 58.7 & 50.5 & 45.6 & 34.4 & 32.6 \\
& $(53.91)$ & $(47.24)$ & $(45.29)$ & $(42.48)$ & $(35.91)$ & $(34.82)$ \\
\hline V2. Kantali & 76.5 & 70.3 & 68.9 & 65.0 & 55.3 & 45.2 \\
& $(61.00)$ & $(51.35)$ & $(56.10)$ & $(53.73)$ & $(48.04)$ & $(42.25)$ \\
\hline V3. Katahi & 73.8 & 70.0 & 63.2 & 60.3 & 60.0 & 45.4 \\
& $(59.21)$ & $(50.31)$ & $(52.65)$ & $(50.94)$ & $(50.77)$ & $(42.36)$ \\
\hline V4. Raksha & 78.2 & 73.6 & 65.7 & 63.2 & 53.8 & 48.1 \\
\hline V5. Tanindo Long & $(62.17)$ & $(52.04)$ & $(54.15)$ & $(52.65)$ & $(47.18)$ & $(43.91)$ \\
\hline V6. Uncha Bolder & 83.3 & 80.3 & 56.4 & 48.4 & 39.7 & 28.0 \\
\hline Mean & $(65.88)$ & $(54.26)$ & $(48.68)$ & $(44.08)$ & $(39.06)$ & $(31.95)$ \\
\hline CD (0.01) & 90.0 & 84.2 & 63.6 & 45.0 & 33.3 & 30.2 \\
\hline CV & $(71.57)$ & $(57.78)$ & $(52.89)$ & $(42.13)$ & $(35.24)$ & $(33.34)$ \\
\hline
\end{tabular}

Number inside the parenthesis indicates arc sine transformed value 
Table.2 Shoot length $(\mathrm{cm})$ of bitter gourd genotypes at different osmotic potential of PEG 6000

\begin{tabular}{|c|c|c|c|c|c|c|}
\hline \multirow[t]{2}{*}{ Genotype } & \multicolumn{6}{|c|}{ Shoot length (cm) } \\
\hline & $\begin{array}{c}\text { 0.0 MPa } \\
\text { (normal) }\end{array}$ & $\begin{array}{l}-0.05 \\
\text { MPa }\end{array}$ & $\begin{array}{c}-0.1 \\
\text { MPa }\end{array}$ & $\begin{array}{r}-0.2 \\
\text { MPa }\end{array}$ & $\begin{array}{c}-0.4 \\
\text { MPa }\end{array}$ & $\begin{array}{c}-0.6 \\
\text { MPa }\end{array}$ \\
\hline V1. Chandramukhi & 10.19 & 7.57 & 5.45 & 4.71 & 4.36 & 3.33 \\
\hline V2. Kantali & 9.27 & 8.37 & 8.34 & 7.73 & 7.24 & 6.76 \\
\hline V3. Katahi & 10.97 & 8.96 & 8.03 & 7.85 & 7.78 & 6.97 \\
\hline V4. Raksha & 10.95 & 9.32 & 7.99 & 6.88 & 6.86 & 6.37 \\
\hline V5. Tanindo Long & 12.56 & 7.81 & 7.27 & 6.96 & 5.12 & 3.83 \\
\hline V6. Uncha Bolder & 11.63 & 9.30 & 9.94 & 6.39 & 6.67 & 6.31 \\
\hline Mean & 10.93 & 8.56 & 7.84 & 6.73 & 6.34 & 5.60 \\
\hline CD (0.01) & 1.08 & 0.86 & 0.81 & 0.81 & 0.72 & 0.71 \\
\hline CV & 3.98 & 4.04 & 4.14 & 4.83 & 4.58 & 5.08 \\
\hline
\end{tabular}

Table.3 Root length to shoot length ratio of bitter gourd genotypes at different osmotic potential of PEG 6000

\begin{tabular}{|l|c|c|c|c|c|c|}
\hline \multirow{2}{*}{ Genotype } & \multicolumn{7}{|c|}{ Root length to shoot length ratio } \\
\cline { 2 - 7 } & $\begin{array}{c}\text { 0.0 MPa } \\
\text { (normal) }\end{array}$ & $\mathbf{- 0 . 0 5}$ & $\mathbf{- 0 . 1}$ & $\mathbf{- 0 . 2}$ & $\mathbf{- 0 . 4}$ & $\mathbf{- 0 . 6}$ \\
\hline V1. Chandramukhi & 0.95 & 0.91 & 1.11 & 1.16 & 1.10 & 1.26 \\
\hline V2. Kantali & 1.26 & 1.00 & 0.80 & 0.76 & 0.73 & 0.74 \\
\hline V3. Katahi & 1.03 & 1.11 & 0.87 & 0.81 & 0.74 & 0.71 \\
\hline V4. Raksha & 1.02 & 0.94 & 0.89 & 0.95 & 0.89 & 0.75 \\
\hline V5. Tanindo Long & 0.97 & 1.20 & 1.00 & 0.70 & 0.91 & 1.18 \\
\hline V6. Uncha Bolder & 1.17 & 1.28 & 1.05 & 0.57 & 0.71 & 0.68 \\
\hline Mean $($ genotype) & $\mathbf{1 . 0 6}$ & $\mathbf{1 . 0 7}$ & $\mathbf{0 . 9 5}$ & $\mathbf{0 . 8 3}$ & $\mathbf{0 . 8 5}$ & $\mathbf{0 . 8 9}$ \\
\hline CD $(\mathbf{0 . 0 1})$ & $\mathbf{0 . 1 0}$ & $\mathbf{0 . 0 8}$ & $\mathbf{0 . 1 0}$ & $\mathbf{0 . 0 9}$ & $\mathbf{0 . 0 9}$ & $\mathbf{0 . 0 6}$ \\
\hline CV & $\mathbf{3 . 9 4}$ & $\mathbf{3 . 0 9}$ & $\mathbf{4 . 2 7}$ & $\mathbf{4 . 5 6}$ & $\mathbf{4 . 1 5}$ & $\mathbf{3 . 7 1}$ \\
\hline
\end{tabular}

Table.4 Seedling length of bitter gourd genotypes at different osmotic potential of PEG 6000

\begin{tabular}{|l|c|c|c|c|c|c|}
\hline \multirow{2}{*}{ Genotype } & \multicolumn{7}{|c|}{ Seedling length $(\mathbf{c m})$} \\
\hline & $\begin{array}{l}\mathbf{0 . 0} \text { MPa } \\
\text { (normal) }\end{array}$ & $\mathbf{- 0 . 0 5}$ & $\mathbf{- 0 . 1}$ & $\mathbf{- 0 . 2}$ & $\mathbf{- 0 . 4}$ & $\mathbf{- 0 . 6}$ \\
\hline V1. Chandramukhi & 19.83 & 14.46 & 11.52 & 10.17 & 9.15 & 7.51 \\
\hline V2. Kantali & 21.00 & 16.77 & 15.00 & 13.62 & 12.50 & 11.77 \\
\hline V3. Katahi & 22.25 & 18.90 & 15.00 & 14.22 & 13.56 & 11.89 \\
\hline V4. Raksha & 22.16 & 18.12 & 15.14 & 13.42 & 12.99 & 11.16 \\
\hline V5. Tanindo Long & 24.70 & 17.16 & 14.55 & 11.82 & 9.78 & 8.34 \\
\hline V6. Uncha Bolder & 25.28 & 21.16 & 13.13 & 15.64 & 11.38 & 10.57 \\
\hline Mean(genotypic) & $\mathbf{2 2 . 5 4}$ & $\mathbf{1 7 . 7 7}$ & $\mathbf{1 4 . 0 6}$ & $\mathbf{1 3 . 1 5}$ & $\mathbf{1 1 . 5 6}$ & $\mathbf{1 0 . 2 1}$ \\
\hline CD $(\mathbf{0 . 0 1})$ & $\mathbf{2 . 9 4}$ & $\mathbf{2 . 0}$ & $\mathbf{1 . 1 2}$ & $\mathbf{1 . 5 6}$ & $\mathbf{1 . 4 8}$ & $\mathbf{1 . 2 3}$ \\
\hline CV & $\mathbf{5 . 2 3}$ & $\mathbf{4 . 5 3}$ & $\mathbf{3 . 9 4}$ & $\mathbf{4 . 0 3}$ & $\mathbf{4 . 3 6}$ & $\mathbf{3 . 9 9}$ \\
\hline
\end{tabular}


Table.5 Seedling dry weight of bitter gourd genotypes at different osmotic potential of PEG 6000

\begin{tabular}{|l|c|c|c|c|c|c|}
\hline Genotype & \multicolumn{7}{|c|}{ Seedling dry weight (g) } \\
\cline { 2 - 8 } & $\begin{array}{c}\mathbf{0 . 0} \text { MPa } \\
\text { (normal) }\end{array}$ & $\mathbf{- 0 . 0 5}$ & $\mathbf{- 0 . 1}$ & $\mathbf{- 0 . 2}$ & $\mathbf{- 0 . 4}$ & $\mathbf{- 0 . 6}$ \\
\hline V1. Chandramukhi & 0.101 & 0.084 & 0.079 & 0.053 & 0.044 & 0.036 \\
\hline V2. Kantali & 0.107 & 0.104 & 0.073 & 0.066 & 0.047 & 0.033 \\
\hline V3. Katahi & 0.113 & 0.102 & 0.090 & 0.075 & 0.057 & 0.042 \\
\hline V4. Raksha & 0.106 & 0.098 & 0.078 & 0.071 & 0.055 & 0.031 \\
\hline V5. Tanindo Long & 0.112 & 0.112 & 0.108 & 0.066 & 0.037 & 0.030 \\
\hline V6. Uncha Bolder & 0.111 & 0.086 & 0.085 & 0.068 & 0.056 & 0.037 \\
\hline Mean(genotype) & $\mathbf{0 . 1 0 8}$ & $\mathbf{0 . 0 9 8}$ & $\mathbf{0 . 0 7 1}$ & $\mathbf{0 . 0 6 7}$ & $\mathbf{0 . 0 4 9}$ & $\mathbf{0 . 0 3 5}$ \\
\hline CD $(\mathbf{0 . 0 1})$ & $\mathbf{0 . 0 0 8}$ & $\mathbf{0 . 0 1 1}$ & $\mathbf{0 . 0 0 8}$ & $\mathbf{0 . 0 0 7}$ & $\mathbf{0 . 0 1 0}$ & $\mathbf{0 . 0 1 2}$ \\
\hline CV & $\mathbf{2 . 8 9}$ & $\mathbf{4 . 3 4}$ & $\mathbf{4 . 5 8}$ & $\mathbf{3 . 2 2}$ & $\mathbf{3 . 7 4}$ & $\mathbf{4 . 1 5}$ \\
\hline
\end{tabular}

Fig.1 Root length $(\mathrm{cm})$ of bitter gourd genotypes at different osmotic potential of PEG 6000

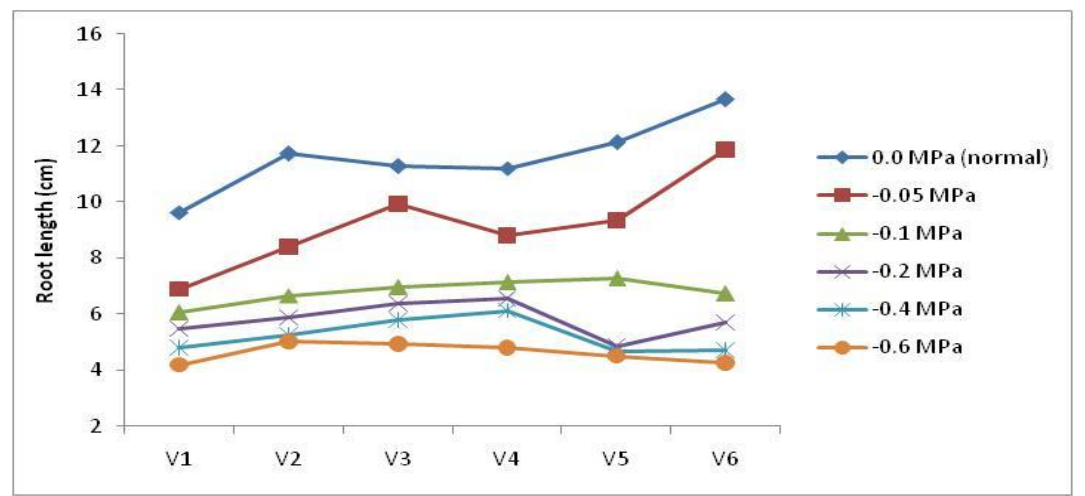

Fig.2 Seed vigour index-I of bitter gourd genotypes at different osmotic potential of PEG 6000

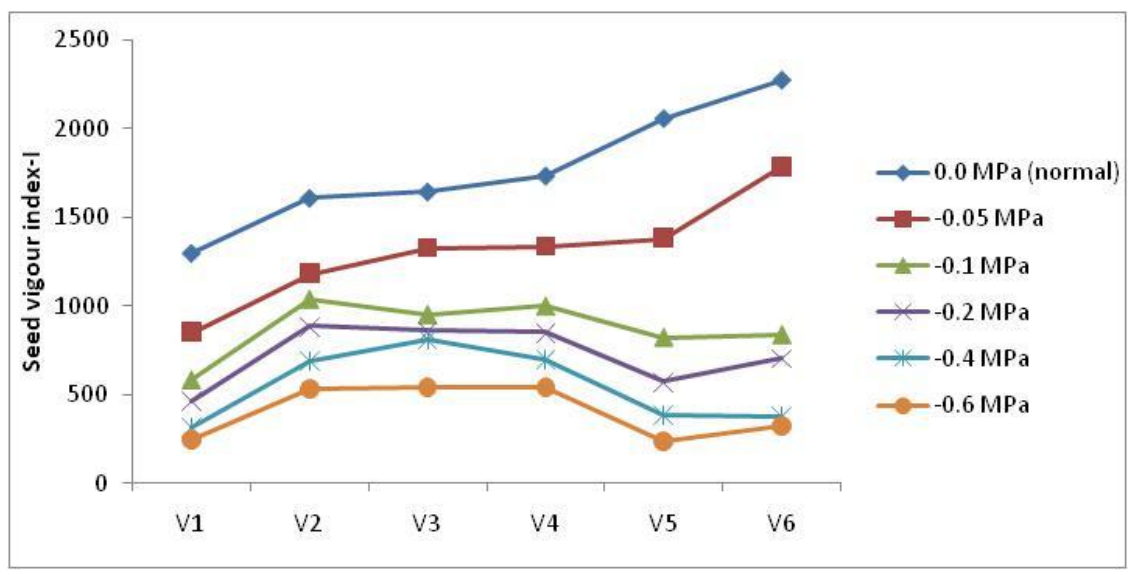


Fig.3 Seed vigour index-II of bitter gourd genotypes at different osmotic potential of PEG 6000

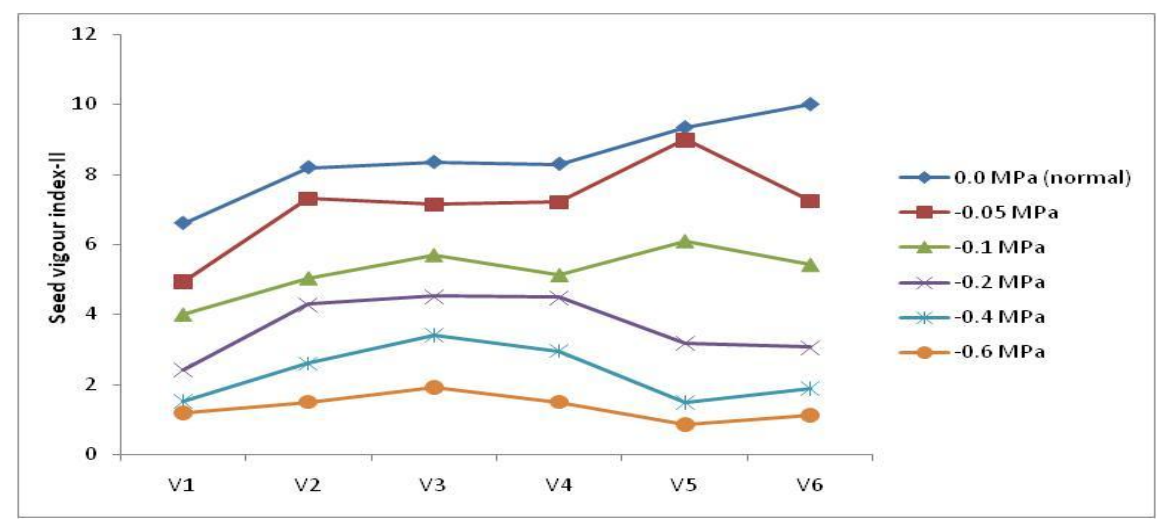

Germination of seeds under water stress should be assessed in the laboratory under controlled temperature and humidity conditions, because, according to Lopes and Takaki (1988) the sensitivity of seeds to water stress can be influenced by different factors such as light, temperature, humidity and oxygen availability. Low water potential in the substrate can be obtained using water solutions containing saccharine, sodium chloride, manitol and polyethylene glycol (Santos et al., 1992). Polyethylene glycol 6000 can be used as an osmotic agent (Hasegawa et al., 1984), because it does not penetrate the cells, cannot be degraded and does not cause toxicity due to its high molecular weight.

In the present study water stress was induced by using PEG 6000 at 0.0 (control), -0.05, $0.1,-0.2,-0.4$ and $-0.6 \mathrm{MPa}$ to assess seed vigour of bitter gourd. Several workers used PEG to study the effect of water stress on germination and seed vigour. Amador et al., (2002) evaluated seeds of some cultivars of cowpea using PEG-8000 solutions of different osmotic potentials $(0,-0.2,-0.4,-0.6$, and -0.8 $\mathrm{MPa}$. Schuab et al., (2007) studied the physiological quality of soybean seeds under water stress conditions using PEG 6000 at 0.0 (control), -0.05, -0.1, -0.2, -0.4 and -0.6 MPa. Santos and Rossetto (2009) evaluated five sunflower lots by the germination and vigour tests with a PEG 6000 solution. Basha et al., (2015) reported that germination and early seedling growth of tomato decreased under PEG-6000 induced water stress condition as compared to normal condition.

From this investigation it may be concluded that germination and seed vigour of bitter gourd genotypes decreased under PEG 6000 induced water stress condition. Fifty percent reduction in germination was observed at -0.6 $\mathrm{MPa}$ as compared to control and this may be treated as optimum stress to distinguish vigorous bitter gourd genotypes.

\section{References}

Amador, M., Lopez-Aguilar, R., Kaya, C., Larrinaga-Mayoral, J. and FloresHernandez, A. 2002. Comparative effects of $\mathrm{NaCl}$ and polyethylene glycol on germination, emergence and seedling growth of cowpea. J. Agronomy \& Crop Science, 188:235-247.

Basha, O., Gudivada, S., Reddy, M. and Siva, N. 2015. Effect of PEG induced water stress on germination and seedling development of tomato germplasm. International Journal of Recent Scientific Research, 6:4044-4049.

Hasegawa, P.M., Bressan, R.A., Handa Sand Handa, A.K. 1984. Cellular mechanisms of tolerance to waterstress. Hort. 
Science, 19:371-377.

Kaur, S., Gupta, A.K. and Kaur, N. 1998. Gibberellic acid and kinetin partially reverse the effect of waterstress on germination and seedling growth in chickpea. Plant Growth Regulation, 25:29-33

Khan, A., Xudong, P., Ullah, N., Daniel, K., Yuen, T., Shahf, R.Z. and Honghai, L. 2018. Coping with drought: stress and adaptive mechanisms, and management through cultural and molecular alternatives in cotton as vital constituents for plant stress resilience and fitness. Biol Res, 51:126-133

Lopes, V.B. and Takaki, M. 1988. Seed germination in Phaseolus vulgaris L. II. Effects of water potential and photoperiod. Arquivos de Biologia $e$ Tecnologia, 31:307-312.

Santos, C. and Rossetto, C. 2009. Germination test under water restriction to evaluate sunflower seeds vigor. Ciencia Rural, 39:2621-2624.

Santos, V.L.M., Calil, A.C., Ruiz, H.A., Alvarenga, E.M. and Santos, C.M. 1992. The effect of salty and hydric stress on germination andvigor of soybean seeds. RevistaBrasileira de Sementes, 14:189-194.

Schuab, S.R.P., Braccini, A.L., Scapim, C.A., França-Neto, J.B., Mesched, D.K. and Avila, M.R. 2007. Germination test under water stress to evaluate soybean seed vigour. Seed Science and Technology, 35:187-199.

Van den Berg, L. and Zeng, Y.J. 2006. Response of South African indigenous grass species to drought stress induced by polyethylene glycol (PEG) 6000. South African Journal of Botany, 72:284-286.

\section{How to cite this article:}

Das, S., S. Sahu, K. C. Muduli, S. Mohanty, M. Priyadarshini, R. Bhol and Beura, J. K. 2020. Effect of PEG Induced Water Stress on Germination and Seed Vigour of Bitter Gourd Genotypes. Int.J.Curr.Microbiol.App.Sci. 9(11): 1196-1206. doi: https://doi.org/10.20546/ijcmas.2020.911.140 